\title{
Takayasus arteritt
}

\author{
Øyvind Palm \\ Revmatologisk avdeling, Rikshospitalet
}

\section{ENGLISH SUMMARY}

Palm Ø. Takayasu arteritis. Nor J Epidemiol 2008; 18 (1): 59-63.

\begin{abstract}
Takayasu arteritis (TA) is a systemic vasculitis, most often affecting young, fertile women. In pre-pulseless phase with systemic inflammation, examination with ultrasound, MRA and ${ }^{18}$ FDG-PET can detect arteritis of the large arteries even before stenosis occurs. Among Caucasians the aorta arch and its branches are most often affected, whereas in Indian cohorts abdominal arteries are most often inflamed. The estimated incidence in Norway of $2.7 /$ million inhabitants corresponds to that of North-Americans, but is based on very few cases. Outcome of pregnancy in TA depends on the distribution and amount of the vasculitis, secondary complications and access of medical follow-up. More focus on TA may result in earlier diagnosis and more multi-center studies should be initiated.
\end{abstract}

\section{INNLEDNING}

Takayasus arteritt (TA) er en systemisk vaskulittsykdom som oftest rammer unge kvinner i fertil alder. Tilstanden er sjelden, men alvorlig. Oftest angripes aorta og dens hovedgrener. TA er rapportert oftest blant asiater (1). Fra Europa publiseres det lite om sykdommen selv om TA forekommer blant etniske europeere, inklusive skandinaver.

Diffuse symptomer plager pasientene i tidlig sykdomsfase og bare målrettet diagnostikk fører til en tidlig diagnose. Ved sykdomsdebut (pre-pulsløs fase) dominerer påfallende tretthet, nattesvette og nedsatt almenntilstand. En finner tegn til myalgi og artralgi hos omkring halvparten, mens artritt er mindre vanlig (2). I løpet av måneder utvikles sykdomsspesifikke symptomer, avhengig av graden av inflammasjon og topografisk affeksjon. Manifestasjonene er forskjellige i ulike befolkningsgrupper (1). Klaudikasjon i en eller begge armer er rapportert av Rødevand hos fire av seks norske pasienter (3) og er også hyppig symptom i Nord-Amerika (4). I India er derimot hypertensjon vanligste debutsymptom $(51,3 \%)(5)$, mens tilsvarende er mindre vanlig blant nordamerikanere (28\%) (4) og var fraværende blant pasientene i den norske studien (3). Vertigo og visuelle forstyrrelser som uttrykk for nevrovaskulær patologi er funnet hos en av tre pasienter ved diagnose i Nord-Amerika $(2,4)$.

Ved klinisk undersøkelse kan en i tidlig sykdomsfase (pre-pulsløs fase) påvise lavgradig feber og forstørrede lymfeknuter. Senere er fraværende puls i a. radialis påfallende (pulsløs fase), slik en viste hos fem av seks norske pasienter (3). I blant oppdages fravær av puls sekundært til at blodtrykksmåling ikke lykkes. Andre funn som indikerer omfattende arterieaffeksjon er: Stenoselyder over a. carotis (36\%), abdominale arterier $(15 \%)$, a. femoralis $(15 \%)$ og a. subclavia $(13 \%)$ (4). TA har således karakteristiske kjennetegn i pulsløs fase, men for en tidligere diagnose er supplerende målrettet utredning nødvendig.

\section{LABORATORIETESTER OG BILLEDDIAGNOSTIKK}

Blodsenkningsreaksjon (SR), C-reaktivt protein (CRP) og andre akuttfaseparametere er oftest markert forhøyet i pre-pulsløs og tidlig pulsløs fase av sykdommen. Aktiv, progredierende vaskulitt til tross for normale inflammasjonsparametere forekommer imidlertid (2). Andre markører er metalloproteinase- 9 og -3 som er funnet å indikere sykdomsaktivitet ved TA. Imidlertid brukes ikke disse rutinemessig ennå (6). Det forskes også på diagnostiske antistoffer. Anti-endotel antistoffer som er benyttet i enkelte studier (7) har dessverre vist lav spesifisitet (8). Nyere analysemetoder kan imidlertid gjøre at slike antistoff blir mer aktuelle i fremtidig diagnostikk (9).

Billeddiagnostisk har konvensjonell, perkutan intravaskulær angiografi vært diagnostisk gullstandard for TA. En påviser segmental affeksjon der stenoser og sjeldnere aneurismer veksler med ikke affiserte områder. Ved CT-angiografi kan en i prestenotisk fase fremstille patologisk fortykket arterievegg som bidrar til å skille forandringene fra arteriosklerose. Undersøkelsesfunn med CT-angiografi viser dessuten god overensstemmelse med konvensjonell angiografi (10). Likevel overtar MR-angiografi (MRA) i økende grad. Teknikken krever ikke arteriepunksjon eller jodholdig kontrastmiddel og benytter ikke røntgenstråler. Ved MR kan en vise inflammasjonstegn $i$ arterieveggen i pre-pulsløs sykdomsfase i tillegg til aktuelle patologiske funn i de store arteriene (11). Ulemper er at MRA ennå har begrenset oppløsning som kan føre til overestimering av okklusjoner eller stenoser (11). MRundersøkelser er også tids- og ressurskrevende. En nylig beskrevet assosiasjon mellom kontrastmiddelet gadolinium og nefrogen systemisk fibrose tilsier forøvrig begrenset bruk dersom nyresykdom foreligger (12). Ved kritisk bruk er likevel MRA et godt verktøy for diagnose og oppfølging ved TA.

Ved ultralyd doppler kan en påvise prestenoserende lesjoner $\mathrm{i}$ a. carotis communis der UL 
kan være 10 ganger mer sensitiv enn MRA (13). Også subclavia-arteriene fremstilles godt, og en kan skille arterieveggens forandringer ved TA fra ateriosklerotiske forandringer.

${ }^{18}$ FDG-PET scan benytter deoxyglukose med Fluorid-18 som tas opp i inflammatorisk vev og avgir radioaktivitet som visualiseres når områdene er større enn 4mm. ${ }^{18}$ FDG-PET og CT kan kombineres (PETCT) og gir da mer nøyaktig anatomisk lokalisasjon av karinflammasjonen ved TA $(14,15)$.

Histologisk undersøkelse av de store arteriene er sjelden aktuelt siden risiko for alvorlig skade og blødning er betydelig. Biopsi tatt ved karoperasjoner eller autopsier viser forekomst av mononukleære celler, særlig lymfocytter, histocytter, makrofager og plasmaceller ved aktiv inflammasjon (16). I media kan også granulomatøs inflammasjon med kjempeceller påvises (17).

\section{SYKDOMSKRITERIER}

ARC-kriteriene av 1990 er de mest brukte klassifikasjonskriteriene (18) (Tabell 1). Disse ble utviklet for å skille TA fra andre typer systemisk vaskulitt. Kriteriene har da høy sensitivitet (90,5\%) og spesifisitet $(97,8 \%)$, men er ikke tiltenkt bruk som "screening" blant uselekterte pasientgrupper. Alderskriteriet på $<40$ år avgrenser TA mot arteritis temporalis. Likevel kan sykdommen debutere senere og dermed være vanskelig å klassifisere. Kriteriene er dessuten basert på undersøkelse av amerikanske pasienter og tar dermed ikke hensyn til at asiatiske pasienter i større grad har affeksjon av abdominale kar. Det er derfor foreslått diagnostiske kriterier $(19,20)$. I de nyere, modifiserte diagnostiske kriteriene (19) er aldersgrensen 40 år eller mindre utelatt. Imidlertid er disse kriteriene ikke tilstrekkelig utprøvd blant kaukasiere.

\section{HistorikK}

Morgani beskrev i 1761 en 40 år gammel kvinne med fraværende puls i a. radialis. Etter en seks år lang sykehistorie, døde pasienten av lungeødem. Post mortem ble det påvist ektatisk proksimal aorta, stenose i nedre thorakalaorta, samt kardial hypertrofi sekundært til aortainsuffisiens, forenlig med TA og et alvorlig sykdomsforløp (21). I Japan ble TA rapportert av Yamamoto i 1830 (22). TA har imidlertid fått sitt navn etter den japanske øyelegen Mikito Takayasu som i 1908 beskrev arterovenøse anastomoser omkring papillen $\mathrm{i}$ retina hos en 21 år gammel kvinne. Det er senere blitt kjent at slike retinaforandringene skyldes kompensatoriske anastomoser ved stenoser i halskar. Pasienten utviklet også katarakt og blindhet, noe som har vist seg å være mindre typisk for tilstanden. Samtidig beskrev Oonisji og Kagoshima, assosiasjoner mellom retina-forandringer og karakteristisk fravær av puls i a. radialis (23). Siden 1939 omtales tilstanden som “Takayasu- eller Takayasu's arteritt”. Synonymer er "pulseless disease", "aortabue-syndrom", "idiopatisk aortitt", "stenoserende aortitt", og "okklusiv trombarteriopati” (21).

I Skandinavia beskrev Waern i 1983 en svensk populasjon på 15 pasienter (24) og Rødevand publiserte i 2001 et materiale på seks etnisk norske pasienter (3). Senere er større norske kohorter beskrevet, men bare i abstrakts form $(25,26)$. Internasjonalt er den hittil største publiserte pasientkohorten fra Kina med 530 tilfeller (27).

\section{FOREKOMST}

Insidensstudier i ulike befolkninger er gjort, men studiene er små og resultatene derfor usikre. Rødevand registrerte fem kvinner og en mann med gjennomsnittsalder 39 år ved debut, behandlet ved Regionsykehuset i Trondheim og Sentralsjukehuset i Møre og Romsdal fra 1988-2000. Beregnet årlig insidens ville vært 0,8/million innbyggere (3), men registreringen var ikke komplett. En gjorde derfor en ny studie i SørTrøndelag fylke og estimerte da årlig insidens til 2,7/mill (25) som er nær identisk med tilsvarende funnet $i$ en nordamerikansk studie: Hall registrerte $i$ perioden 1971-82 i alt 32 pasienter (26 kvinner, seks menn) svarende til en insidens på 2,6/mill (28). I Kuwait ble 13 pasienter (åtte kvinner, fem menn) inkludert over en $41 / 2$ års periode, og en estimerte insidens til 2,2/mill (29). Fra Asia, rapporteres om høyere forekomst av TA enn i andre befolkninger (30), og andelen menn er relativ høy (39\%) (5), men direkte sammenlignbare insidensstudier mellom ulike land og verdensdeler foreligger ennå ikke.

Tabell 1. ACR-kriterier for diagnosen TA (18).

1. Alder ved sykdomsdebut $<40$ år:

Utvikling av symptomer eller funn som relateres til TA ved alder før 40 års alder

2. Symptomer på nedsatt sirkulasjon: Symptomer på klaudiksjon i en eller flere ekstremiteter ved muskelbruk, spesielt i overekstremitetene

3. Nedsatt arteriepuls i armene: Redusert pulsasjon i en eller begge a. brachialis.

4. Blodtrykksforskjell $>10 \mathrm{mmHg}$ : $>10 \mathrm{mmHg}$ forskjell i systolisk blodtrykk mellom armene

5. Bilyd over subclaviaarteriene eller aorta: Auskultatorisk bilyd over en eller begge subclaviaarteriene eller abdominalaorta

6. Patologisk arteriogram: Ved angiografi påvist avsmalning eller okklusjon av aorta, dens primære grener eller store arterier proksimalt $\mathrm{i}$ over- eller underekstremiteter. Andre årsaker som ateriosklerose, fibromuskulær dysplasi eller lignende årsaker må utelukkes.

Sensitivitet $90,5 \%$, spesifisitet $97,8 \%$ dersom tre eller flere av punktene er til stede 
Prevalensen av TA er ikke systematisk kartlagt. I en eldre japansk studie fant en TA i en av 3000 autopsier, svarende til prevalens på 33/100.000 (17). Studien er imidlertid liten og sannsynligvis beheftet med betydelig seleksjon. En overestimering av forekomsten er derfor trolig. I Uppsala-regionen registrerte Wearn 15 pasienter med TA, alle kvinner, fulgt over en åtte års periode (1969-76). Hele syv døde under observasjonsperioden. Også denne studien bygger således på et lite pasientantall, og det forelå uvanlig stor dødelighet. Den beregnede prevalensen på 0,64/100.000/år innbyggere (24) må derfor oppfattes som usikker.

\section{ETIOLOGI, GENETIKK OG PATOGENESE}

En har ikke funnet bevis for at utløsende infeksjoner med spesifikke agens, som streptokokker, spirocheter, mycobakterier og ulike virus er av betydning for sykdomsutviklingen $(31,32)$.

Familiær forekomst av TA blant monozygote tvillinger, blant søsken og hos mor og datter er rapportert $(33,34)$. Også økt forekomst av vevstypene HLA-B52 og HLA-DR4 blant pasienter i ulike etniske populasjoner tyder på en genetisk sykdomsdisposisjon. Likevel viser epidemiologiske pasientkohorter at nære slektninger vanligvis ikke affiseres.

Sykdommens etiologi er ukjent, men patogenetisk antas klasse II-presenterende HLA-molekyler å spille en rolle ved antigen stimulering av $\mathrm{CD}^{+} \mathrm{T}$-celler (35). Ett eller få antigen lokalisert i aortaveggens endoteliale celler kan være mål for slike stimulerte, infilterende Tceller. Vaskulær celleskade skjer ved frigjøring av store mengder membran-skadende protein (perforin) direkte mot celleoverflaten i arteriene (9). Skader i arterieveggen antas dermed forårasket av T-celler, kjemokiner og cytokiner. Hvilken rolle B-celler spiller, vet vi ennå mindre om (35). Terapeutisk er intervensjon i cytokinproduksjonen lovende og kan gi flere terapeutiske muligheter i fremtiden $(35,36)$.

\section{SVANGERSKAP}

De fleste pasienter som får TA er kvinner i fertil alder, og informasjon om sykdomsrisiko og forløp under svangerskap etterspørres ofte. Studieresultater som besvarer dette er imidlertid mangelvare. Kerr beskriver fem svangerskap ved TA. Tre hadde aortalesjoner både over og under diafragma, ingen hadde hypertensjon. Alle fødte friske barn ved spontan, vaginal fødsel (2). I studien til Maksimowicz-McKinnon ble fire pasienter gravide hvorav en spontanaborterte i uke 25. De øvrige hadde vellykkede svangerskap og fødte friske barn (4). Grunn til mer bekymring gir en indisk studie med totalt 124 pasienter fulgt over en 20 års periode. I alt 12 kvinner hadde til sammen 24 svangerskap. I løpet av svangerskapene registrerte en alvorlig hypertensjon hos elleve kvinner (92\%), hjertesvikt hos to, og en hadde arrytmi. Fire pasienter utviklet preeklampsi, to fikk progressiv nyresvikt og en post-partum sepsis. Av
17 levende fødte barn (71\%), hadde fem (29\%) tegn på intrauterin vekstretardasjon og fire $(24 \%)$ ble født prematurt. Intrauterin fosterdød forelå i fem- og spontanabort i to svangerskap. Forfatterne bemerker at pasientene fikk sen medisinsk oppfølging, noe som kan ha bidratt til det dårlige utfallet (37). En japansk studie rapporterte 23 svangerskap hos 15 pasienter. Fire svangerskap ble avsluttet ved provosert abort i første trimester grunnet høy sykdomsaktivitet. De øvrige 16 svangerskap forløp normalt (38).

Svangerskapets påvirkning på sykdomsaktiviteten ble undersøkt i en annen japansk studie. Parametre for inflammasjon og hemodynamikk ble målt før, under og etter graviditet. En konkluderte med at inflammatorisk aktivitet og hemodynamisk status ble bedret under svangerskap, og det kom ikke til forverring etter fødsel (39).

Samlet sett tyder studiene på at svangerskap ved TA innebærer økt risiko for pasient og foster. Kjent organskade med nyrearterieaffeksjon og hypertoni er prognostisk ugunstig. Før svangerskap må pasientene informeres godt om risiko og behov for tett oppfølging under graviditeten. En grundig kartlegging og monitorering av blodtrykk, kardiovaskulær status og nyrefunksjon er aktuelt. Således bør svangerskapsoppfølging skje i samarbeid mellom revmatolog og svangerskapspoliklinikk. Kardiolog og nefrolog må kunne konsulteres ved behov.

\section{Prognose og Mortalitet}

Dagens behandling bringer sjelden TA til vedvarende remisjon. Maksimowicz-McKinnon fant at tre år etter diagnose hadde ennå 25 av 30 pasienter (83\%) aktiv sykdom. Iskjemiske komplikasjoner forelå hos mange: 18 pasienter $(60 \%)$ hadde vaskulær klaudikasjon som påvirket daglige aktiviteter. Fem pasienter (17\%) hadde cerebral iskjemisk sykdom (to TIA og tre slag). Ved intervju av 34 pasienter fant Kerr at hele 25 pasienter (74\%) i varierende grad var fysisk påvirket av sykdommen. Til sammen 16 (47\%) var uføretrygdet (2). I en norsk kohorte som gjennomsnittlig hadde vært syke i 15 år fant vi at 20 av 26 pasienter (77\%) ikke var i arbeid (26), tydende på at sykdommen over tid påvirker fysisk ytelse og evnen til inntektsgivende arbeid i stor grad.

Blant 69 indiske pasienter, var prognosen vesentlig relatert til nyrearterieaffeksjon. Over en 16 års periode utviklet syv pasienter (10\%) nyresvikt og fem $(7,2 \%)$ fikk hjertesvikt.

Det foreligger flere rapporter som beskriver mortalitet, men resultatene er ikke entydige. I studien til Wearn døde hele seks av 15 pasienter (40\%) under åtte års observasjon. Medvirkende til den høye dødeligheten kan være at fire var røkere og tre hadde hyperkolestrolemi. Dødsårsak var "plutselig død" hos fire og henholdsvis slag og uremi i to tilfeller. Alle unntatt en med letal utgang led av angina pectoris og intermitterende klaudikasjon. Tiden mellom diagnose og død var 
gjennomsnittlig 11 år (24). Atskillig lavere risiko for død tyder observervasjoner fra bindevevsregisteret ved Rikshospitalet på. Blant 30 pasienter med TA observert i opptil åtte år, var ved analyse primo 2007 ingen døde (26). I den nordamerikanske studien til Maksimowicz-McKinnon forelå to sykdomsrelaterte dødsfall, begge henholdsvis en og to måneder etter karkirurgiske inngrep (4). Blant indiske pasienter fulgt opptil 16 år døde 12 (17\%), herav fire av cardial svikt, to av nyresvikt og tre av henholdsvis cerebral blødning, myokardinfarkt og aneurismeruptur. I tre tilfeller var dødsårsaken ukjent (5).

Studiene tyder dermed på at sykdommen på sikt gir komplikasjoner som påvirker den fysiske funksjonen og arbeidsevnen. Mortalitet er imidlertid svært varierende mellom kohortene og synes å være særlig høy ved samtidig kardiovaskulær sykdom og blant indiske pasienter.

\section{KONKLUSJON OG ANBEFALING}

Internasjonalt er TA hyppigst beskrevet blant asiater, men også norsk-ættede og andre befolkningsgrupper rammes. Økt innvandring av spesielt utsatte befolkningsgrupper tilsier behov for mer oppmerksomhet omkring sykdommen og de ulike komplikasjoner i befolkningene. Tegn på vedvarende systemisk inflammasjon er tidlige symptomer, mens en finner klaudika- sjon, stenoselyder og fravær av a. radialispuls senere $\mathrm{i}$ forløpet. Kartlegging ved hjelp av MRA, ultralyd doppler, CT-angiografi og ${ }^{18}$ FDG-PET-scan vil vise utbredelsen av karaffeksjonen og bekrefte diagnosen. Sykdommen affiserer hyppig kvinner i fertil alder og sykdomsinformasjon og tett oppfølging ved svangerskap anbefales. Det er behov for å evaluere forekomst, alvorlighetsgrad, forløp samt behandlingsrespons både i norske og internasjonale studier. Siden sykdommen er sjelden, bør multisenterstudier gjøres. Ved oppfølging over tid, bør sykdomsregistreringer i tråd med internasjonale anbefalinger gjøres (40).

\section{HOVEDBUDSKAP}

- TA affiserer hyppigst unge kvinner.

- I "prepulseless fase" foreligger systemisk inflammasjon, men utredning med ultralyd, MRA, CTangiografi og ${ }^{18}$ FDG-PET kan vise inflammasjon $\mathrm{i}$ store kar før stenoser oppstår.

- Blant kaukasiere affiseres aortabuen og tilgrensende arterier hyppigst, mens tilsvarende hos indiske pasienter er abdominalaorta og nyrearterier.

- Svangerskapsutfall er avhengig av sykdomsutbredelsen og god medisinsk oppfølging.

- Økt oppmerksomhet om tilstanden for tidligere diagnose samt gjennomføring av nasjonale studier anbefales.

\section{REFERANSER}

1. Numano F. Differences in clinical presentation and outcome in different countries for Takayasu's arteritis. Curr Opin Rheumatol 1997; 9: 12-5.

2. Kerr GS, Hallahan CW, Giordano J, Leavitt RY, Fauci AS, Rottem M et al. Takayasu arteritis. Ann Intern Med 1994; 120: 919-29.

3. Rødevand E, Skomsvoll JF, Wallenius M, Henriksen AZ, Skjaerpe T, Tafjord AB. Takayasu's arteritt. Tidsskr Nor Lageforen 2001; 121: 173-6.

4. Maksimowicz-McKinnon K, Clark TM, Hoffman GS. Limitations of therapy and a guarded prognosis in an american cohort of Takayasu arteritis patients. Arthritis Rheum 2007; 56: 1000-9.

5. Jain S, Kumari S, Ganguly NK, Sharma BK. Current status of Takayasu arteritis in India. Int J Cardiol 1996; 54 (Suppl): S111-6.

6. Matsuyama A, Sakai N, Ishigami M, Hiraoka H, Kashine S, Hirata A et al. Matrix metalloproteinases as novel disease markers in Takayasu arteritis. Circulation 2003; 108: 1469-73.

7. Eichhorn J, Sima D, Thiele B, Lindschau C, Turowski A, Schmidt H et al. Anti-endothelial cell antibodies in Takayasu arteritis. Circulation 1996; 94: 2396-401.

8. Holmen C, Christensson M, Pettersson E, Bratt J, Stjarne P, Karrar A et al. Wegener's granulomatosis is associated with organ-specific antiendothelial cell antibodies. Kidney Int 2004; 66: 1049-60.

9. Chauhan SK, Tripathy NK, Nityanand S. Antigenic targets and pathogenicity of anti-aortic endothelial cell antibodies in Takayasu arteritis. Arthritis Rheum 2006; 54: 2326-33.

10. Yamada I, Nakagawa T, Himeno Y, Numano F, Shibuya H. Takayasu arteritis: evaluation of the thoracic aorta with CT angiography. Radiology 1998; 209: 103-9.

11. Desai MY, Stone JH, Foo TK, Hellmann DB, Lima JA, Bluemke DA. Delayed contrast-enhanced MRI of the aortic wall in Takayasu's arteritis: initial experience. Am J Roentgenol 2005; 184: 1427-31.

12. Grobner T, Prischl FC. Gadolinium and nephrogenic systemic fibrosis. Kidney Int 2007; 72: 260-4.

13. Kissin EY, Merkel PA. Diagnostic imaging in Takayasu arteritis. Curr Opin Rheumatol 2004; 16: 31-7.

14. Kobayashi Y, Ishii K, Oda K, Nariai T, Tanaka Y, Ishiwata K et al. Aortic wall inflammation due to Takayasu arteritis imaged with 18F-FDG PET coregistered with enhanced CT. J Nucl Med 2005; 46: 917-22. 
15. Yamada I, Nakagawa T, Himeno Y, Kobayashi Y, Numano F, Shibuya H. Takayasu arteritis: diagnosis with breath-hold contrast-enhanced three-dimensional MR angiography. J Magn Reson Imaging 2000; 11: 481-7.

16. Fassbender H. Pathology and pathobiology of rheumatic diseases. Berlin: Springer-Verlag, 2002: 304.

17. Nasu T. Takayasu's truncoarteritis in Japan. A statistical observation of 76 autopsy cases. Pathol Microbiol (Basel) 1975; 43: 140-6.

18. Arend WP, Michel BA, Bloch DA, Hunder GG, Calabrese LH, Edworthy SM et al. The American College of Rheumatology 1990 criteria for the classification of Takayasu arteritis. Arthritis Rheum 1990; 33: 1129-34.

19. Sharma BK, Jain S, Suri S, Numano F. Diagnostic criteria for Takayasu arteritis. Int J Cardiol 1996; 54 (Suppl): S141-7.

20. Ishikawa K. Diagnostic approach and proposed criteria for the clinical diagnosis of Takayasu's arteriopathy. $J$ Am Coll Cardiol 1988; 12: 964-72.

21. Watts R, Scott DGI. Large vessel vasculitis. In: Maddison PJ, Isenberg DA, Woo P, Glass DN, eds. Oxford Textbook of Rheumatology. Oxford: Oxford University Press, 1998: 1382-94.

22. Numano F, Katuka T. Takayasu Arteriti - Five doctors in the history of Takayasu Arteritis. Int J Cardiol 1996; 54 (suppl): 1-10.

23. Numano F. The story of Takayasu arteritis. Rheumatology 2002; 41: 103-6.

24. Waern AU, Andersson P, Hemmingsson A. Takayasu's arteritis: a hospital-region based study on occurrence, treatment and prognosis. Angiology 1983; 34: 311-20.

25. Rødevand E, Skomsvoll JF, Koksvik HS, Grønning K. Takayasu Arteritis. Scand J Rheumatol 2004; 33: 130.

26. Garen T, Palm O, Gran J. A hospital based registry of Takayasu Arteritis in Southern Norway. Ann Rheum Dis 2007; 66 (Suppl II): 385.

27. Zheng D, Fan D, Liu L. Takayasu arteritis in China: a report of 530 cases. Heart Vessels Suppl 1992; 7: 32-6.

28. Hall S, Barr W, Lie JT, Stanson AW, Kazmier FJ, Hunder GG. Takayasu arteritis. A study of 32 North American patients. Medicine 1985; 64: 89-99.

29. el Reshaid K, Varro J, al Duwairi Q, Anim JT. Takayasu's arteritis in Kuwait. J Trop Med Hyg 1995; 98: 299305.

30. Numano F, Kobayashi Y. Takayasu arteritis - beyond pulselessness. Intern Med 1999; 38: 226-32.

31. Somer T, Finegold SM. Vasculitides associated with infections, immunization, and antimicrobial drugs. Clin Infect Dis 1995; 20: 1010-36.

32. Rodriguez-Pla A, Stone JH. Vasculitis and systemic infections. Curr Opin Rheumatol 2006; 18: 39-47.

33. Numano F, Isohisa I, Kishi U, Arita M, Maezawa H. Takayasu's disease in twin sisters. Possible genetic factors. Circulation 1978; 58: 173-7.

34. Valentini F, Di Folca A. Takayasu's disease. A review of the literature. A study of a familial case of Takayasu's arteritis and the possible associations with type-1 diabetes mellitus. Minerva Med 1989; 80: 1351-8.

35. Arnaud L, Kahn JE, Girszyn N, Piette AM, Bletry O. Takayasu's arteritis: An update on physiopathology. Eur J Intern Med 2006; 17: 241-6.

36. Hoffman GS, Merkel PA, Brasington RD, Lenschow DJ, Liang P. Anti-tumor necrosis factor therapy in patients with difficult to treat Takayasu arteritis. Arthritis Rheum 2004; 50: 2296-304.

37. Sharma BK, Jain S, Vasishta K. Outcome of pregnancy in Takayasu arteritis. Int J Cardiol 2000; 75 (Supp1 1): S159-62.

38. Aso T, Abe S, Yaguchi T. Clinical gynecologic features of pregnancy in Takayasu arteritis. Heart Vessels Suppl 1992; 7: 125-32.

39. Matsumura A, Moriwaki R, Numano F. Pregnancy in Takayasu arteritis from the view of internal medicine. Heart Vessels Suppl 1992; 7: 120-4.

40. Hellmich B, Flossmann O, Gross WL, Bacon P, Cohen-Tervaert JW, Guillevin L et al. EULAR recommendations for conducting clinical studies and/or clinical trials in systemic vasculitis: focus on anti-neutrophil cytoplasm antibody-associated vasculitis. Ann Rheum Dis 2007; 66: 605-17. 